\title{
The United States Supreme Court case Ziglar v. Abbasi and the severe psychological and physiological harms of solitary confinement
}

\author{
Eric Ordway, Esq.*i, Jessica Djilani, Esq.** , Alexandria Swette, Esq.**
}

Key points of interest:

- A group of men were arrested for immigration violations and held as "terrorism suspects" after the September 11, 2011 attacks.

- In a 2016 United States Supreme Court case, a group of medical, scientific, and health-related professionals filed an amicus brief, in support of the men.

- The amicus brief discussed the overwhelming medical and scientific research, spanning decades and countries, which demonstrates that prolonged solitary confinement causes severe psychological and physiological trauma and damage.

- It also highlighted that international legal standards and the laws of other countries have condemned the use of solitary confinement for over fifteen days as cruel and inhumane treatment, and, in some cases, torture.

- This comprehensive summary of the numerous studies on solitary confinement is a model for others seeking to challenge the future use of this practice.

\section{Introduction}

In the aftermath of the September 11, 2001 terrorist attacks, a group of Middle Eastern, North African, and South Asian men was arrested for immigration violations, held as "terrorism suspects," and detained in federal prison for months. Each of these men was, or was believed to be, Muslim or Arab. These men (the "Detainees") alleged that they were detained solely on the basis of their religion or race, and that there was no individualized basis to suspect them of terrorism. They further alleged that, during their detention, they were abused physically and verbally and subjected to inhumane conditions, including solitary confinement. After several months, the Detainees were cleared of any connection to terrorism and deported. The Detainees allege that they suffered severe psychological and physiological harms as a result of the conditions of their detention and that they continue to suffer the effects of this trauma today.

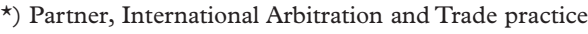
group, Weil, Gotshal \& Manges LLP.

$\star \star)$ Associates, Securities Litigation practice group, Weil, Gotshal \& Manges LLP.

${ }^{i}$ All three contributors are also co-authors of the legal submission that is the subject of this article.

Correspondence to: eric.ordway@weil.com 
In 2002, the Center for Constitutional Rights ${ }^{\mathrm{i}}$ filed a federal lawsuit in New York on behalf of a group of these Detainees seeking money damages from United States government officials to remedy the constitutional violations against them. The case languished for a number of years until 2015, when the Court of Appeals for the Second Circuit ruled that the high-level officials named as defendants could be sued for damages for their roles in the religious profiling, detention, and abuse of the Detainees. In 2016, the government sought permission to appeal this decision to the Supreme Court of the United States. The Supreme Court heard oral argument on the case in January 2017 and rendered its decision in June 2017.

In support of the Detainees and their claims against the high-level officials, several interested groups submitted briefs to the Supreme Court as amicus curiae, or "friends of the court." Amicus curiae briefs are written by a person or group who is not a party to a lawsuit but has a strong interest in the action, can provide a unique perspective on the subject matter at issue, and seeks to influence the court's decision. One of these briefs, the Brief of Medical And Other Scientific And Health-Related Professionals As Amici Curiae (the "Solitary Confinement Brief" or "Brief") focused on a particular aspect of the abusive conditions of the Detainees' imprisonment: the use of solitary

\footnotetext{
${ }^{\mathrm{i}}$ https://ccrjustice.org/

ii Available at: https://ccrjustice.org/sites/default/files/ attach/2016/12/Medical_and_Other_Scientific_and_ Health-Related_Professionals_Amicus.pdf. Several other organizations and groups also filed amicus curiae briefs with the Supreme Court on behalf of the Detainees including, among others, the American Civil Liberties Union, the American Association for Justice, and a group of former correctional officers.

iii Additional information about the case, including a case timeline, is available at https://ccrjustice.org/ziglar-v-abbasi.
}

confinement. The Brief was submitted on behalf of a group of medical, scientific, and health-related professionals who have extensive experience studying the psychological and physiological effects of solitary confinement and who are committed to limiting the application of the practice (Brief Of Medical And Other Scientific And Health-Related Professionals As Amici Curiae In Support Of Respondents And Affirmance, Ziglar v. Abbasi, No. 151358(Dec. 22, 2016)).i

The Brief considered the issue of solitary confinement from a global perspective and demonstrated that the overwhelming medical and scientific consensus, spanning decades and countries, is that prolonged solitary confinement causes severe psychological and physiological trauma and damage. The Brief also highlighted that, in recognition of the severe pain and suffering inflicted by prolonged solitary confinement, international legal institutions have condemned its use for over fifteen days as cruel and inhuman treatment and, in some cases, as torture. The Brief thus urged the Supreme Court to permit the Detainees to pursue their constitutional claims against the government officials and to seek damages against them for the harms the Detainees endured while imprisoned. This article discusses the facts giving rise to the case and the scientific evidence on solitary confinement submitted in the Solitary Confinement Brief.

Keywords: Solitary Confinement, Detention, Immigration, Prisoner rights, Torture, Cruel and inhumane treatment, Racial profiling, Amicus, Psychological harm, US law, Constitutional law

\section{Procedural Background of Ziglar v. Abbasiiii}

Ziglar v. Abbasi involves the claims of eight 
men, Ibrahim Turkmen, Akhil Sachdeva, Ahmer Iqbal Abbasi, Anser Mehmood, Benamar Benatta, Ahmed Khalifa, Saeed Hammouda, and Purna Bajracharya. These men are of Middle Eastern, North African, or South Asian origin; six of them are Muslim, one is Hindu, and one is Buddhist (Memorandum Opinion at 6, Turkmen v. Hasty, No. 13-981 (2d Cir. Jun. 17, 2015 )). At the time they were arrested, these Detainees were "out-of-status" aliens, i.e., persons who had either (1) entered the United States illegally or (2) entered the United States legally but fell "out of status" by violating the rules or guidelines for their non-immigrant status (often by overstaying their visas) in the United States and were legally deportable (Ibid, p. 4).

The Detainees brought claims against high-level Bush administration officials, including John Ashcroft (the former Attorney General), Robert Mueller (the former Director of the FBI), James Ziglar (the former Commissioner of the Immigration and Naturalization Services), Dennis Hasty (the former warden of Metropolitan Detention Center in Brooklyn, New York (the “MDC”)), Michael Zenk (another former warden of the MDC), and James Sherman (former MDC Associate Warden for Custody) (together, the "Government Officials"), for their roles in the post-9/11 profiling and abuse of the Detainees. The Detainees' claims were brought as a "Bivens

\footnotetext{
iv Prior to Bivens, the United States legislation had not provided a damages remedy to individuals whose constitutional rights had been violated by agents of the federal government. A Bivens remedy is available in cases involving constitutional violations unless Congress has expressly curtailed that right of recovery or "special factors counselling hesitation" exist.

v The due process clause of the Constitution protects persons from intrusions by the government into a their life, liberty or property, without due process of law.
}

action," so-named after the 1971 case of Bivens v. Six Unknown Named Agents of Federal Bureau of Narcotics, in which the Supreme Court of the United States held that lawsuits for money damages may be brought against federal officers for certain constitutional violations. ${ }^{\text {iv }}$

The Detainees brought several claims in this action:

(1) a claim challenging the conditions of their confinement under the due process clause of the United States Constitution (the "Constitution");

(2) a claim alleging that Defendants subjected Plaintiffs to the challenged conditions because of their actual, or perceived, race, religion, ethnicity, and/or national origin, and thereby violated the equal protection clause of the Constitution; ${ }^{\text {vi }}$

(3) a claim arising under the free exercise clause of the Constitution; ;ii $^{\text {vi }}$

(4) and (5) two claims generally alleging interference with counsel;

(6) a claim under the Fourth and Fifth Amendments of the Constitution alleging unreasonable and punitive strip searches; ${ }^{\text {viii }}$ and,

(7) a claim for conspiracy to interfere with civil rights under the United States Code.

In May 2016, the Government Officials petitioned the Supreme Court to overturn the Second Circuit's decision that the Detainees were permitted to bring these claims. After the Supreme Court agreed to hear the case, briefs for the Detainees,

${ }^{\text {vi }}$ The equal protection clause of the Constitution ensures that all people are protected equally under the law. vii The free exercise clause of the Constitution prohibits the government from interfering with a person's exercise of his or her religion.

viii The Fourth Amendment of the Constitution protects people against unreasonable searches and seizures of property and arbitrary arrests by the government. 
including the amicus curiae briefs, were filed. The case was argued before the Supreme Court on January 18, 2017.

On June 19, 2017, the Supreme Court, in a 4-to-2 decision, held that the claims against all of the Government Officials (except for those against Warden Hasty of the MDC) ${ }^{\text {ix }}$ were insufficient as a matter of law, and prohibited the Detainees from seeking damages for their harms. Ziglar v. Abbasi, No. 15-1358, 137 S. Ct. 1843 (2017). ${ }^{\mathrm{I}}$ In dismissing the Detainees' claims, the Court applied a "special factors" analysis and concluded that a Bivens-type of damages remedy could not be extended to the Detainees' claims. Specifically, the Court reasoned that permitting the Detainees' claims for damages to go forward in this context would permit courts to inquire into issues of national security and interfere with the sensitive functions of the Executive Branch of the United States government, which had set the policy adopted by the Government Officials in the wake of the September 11th attacks. Accordingly, the Court determined that Congress - not the Supreme Court - should decide whether these type of claims should be allowed (Ibid, p. 1860-63).

In a powerful dissent, Justice Breyer, joined by Justice Ginsburg, argued that a Bivens action could not be extinguished even though the Detainees' claims concerned the actions of high-level Government Officials

\footnotetext{
ix The Supreme Court remanded the Detainees' claim for prisoner abuse against Warden Hasty to the lower court for additional analysis, finding that the Detainees' prisoner abuse allegations against Mr. Hasty state a plausible ground to find a constitutional violation if a Bivens-type damages remedy is found to be proper under the "special factors" analysis.

x The Supreme Court's opinion can be found at https:// ccrjustice.org/sites/default/files/ attach/2017/06/2017-06-19_ZiglarvAbbasi_ SCOTUSdecision.pdf.
}

and a detention policy that occurred after a serious attack on the United States. The dissenting opinion stressed the seriousness of the Detainees' claims and the importance of the role that courts must play in checking abuses of executive power. Comparing the majority's decision to other regrettable episodes in America's history, Justice Breyer wrote that "[i]n wartime as well as in peacetime, it is important, in a civilized society, that the judicial branch of the Nation's government stand ready to afford a remedy for the most flagrant and patently unjustified unconstitutional abuses of official power" (Ibid, p. 1873).

\section{Harms Suffered By the Detainees}

In their Complaint, the Detainees alleged that, while incarcerated at the MDC, they were subjected to physical and psychological abuse and held in brutal conditions, including placement in solitary confinement in the Administrative Maximum Special Housing Unit ("ADMAX SHU”). As described in the Complaint, "[e]ach Detainee was confined to a 'tiny cell[]' for 'at least 23 hours a day,' alone or with one other detainee, for months on end." (Brief, p. 5). "The cells were completely 'bare'; no property, not 'even toilet paper' or 'other personal hygiene items,' were kept in the cells (Ibid.). " "“[B]right lights were kept on in the cells ... 24 hours a day, causing sleep deprivation" (Ibid) and the Detainees could not even manufacture darkness by covering their faces (Ibid, p. 23). Because prison rules forbade detainees to cover their heads while lying in bed at night, they had no escape from the constant light (Ibid). In addition, "the cells were 'very cold at night." (Ibid, p. 5.)

The Detainees alleged that, for the first month, they "were 'denied all recreation' outside their cells and subjected to a 'communications blackout' forbidding 'any social 
or legal visits or telephone calls.” (Ibid). Then, "[e]ven after the bans were lifted, the [D]etainees were deterred from recreation by the extreme cold in the outdoor recreation 'cages,' subjected to grossly humiliating mandatory strip-searches, suffered abuse in transport, and were routinely denied the weekly legal calls and monthly social calls technically permitted." (Ibid.). Indeed, four of the Detainees were not permitted a single social visit throughout their imprisonment in the ADMAX SHU (Ibid).

In addition, the Muslim Detainees alleged that they were "denied access to the Koran, religiously appropriate food, and the means to maintain their daily prayer requirements." (Ibid, p. 31). They also alleged that they were "punished for praying ... one received an incident report for refusing to stand up for count during prayer, while others were unable to obtain razors or hygienic supplies (which guards purposely passed out during prayer times)." (Ibid).

As alleged in the Complaint, the conditions of the Detainees' restrictive and isolated confinement caused them to suffer significant psychological and physiological trauma. For example, the Detainees suffered severe sleep deprivation as a result of the constant light and cold temperatures. The Complaint alleged that one Detainee, Saeed Hammou$\mathrm{da}$, would restlessly pace in his small cell to induce fatigue. (Fourth Amended Complaint, Turkmen v. Ashcroft, No. 02 CV 2307 (SMG) (E.D.N.Y. Sept. 13, 2010) (the "Complaint”), para. 223). Another Detainee, Purna Raj Bajracharya, who was kept in an ADMAX SHU cell completely alone for two months, "we[pt] constantly" during his confinement, thought he was "going crazy," reported suicidal thoughts, and "scream[ed] to guards that he was going to die." (Ibid, para. 241). The Complaint further alleged that, "after a bout of sleepless nights",
Benmar Benatta "'snapped' and began banging his head against the bars of his cell."(Brief, p. 23). He was so distraught over his "inexplicable, prolonged, and arbitrary confinement" that he twice attempted to injure - or possibly kill - himself by repeatedly banging his head into the walls and bars of his cell. (Complaint, paras. 179-82). On another occasion, he used a plastic spoon to cut himself (Ibid, para. 206).

According to the Complaint, the effects of solitary confinement continue to plague the Detainees to this day, long after their release. The Complaint alleges that "[s] everal have trouble with concentrating, communicating, trusting others, sleeping, studying, and finding work and some have lost their homes, businesses, or jobs." (Brief, pp. 18-19). The Detainees now "face numerous long-term and potentially permanent mental health issues, including post-traumatic stress disorder, depression, anger, isolation, fear of travel, difficulties handling open areas or light, and an inability to enjoy life.” (Brief, p. 19).

\section{The Solitary Confinement Brief}

The Brief addressed the scientific evidence regarding the psychological and physiological consequences of solitary confinement. The term "solitary confinement," as used in the international medical and legal literature and throughout the Brief, refers to "the confinement of prisoners for 22 hours or more a day without meaningful human contact." (Brief, p. 2 citing the Nelson Mandela Rules, 2015, Rule 44).

Nineteen prominent medical and other scientific and health-related professionals from all over the world (the "Amici") sponsored the Brief in support of the Detainees, including a member of the United Nations Subcommittee for the Prevention of Torture, experts from the World Health Organization and World Psychiatric Associa- 
tion, pre-eminent psychologists and psychiatrists, prison health services experts, neuroscientists, physicians and medical professors. The Amici have extensive experience studying the psychological and physiological effects of solitary confinement and other punitive conditions of incarceration.

The Amici advanced two principal points: First, the overwhelming medical and scientific consensus, spanning decades and countries, demonstrates that prolonged solitary confinement causes severe psychological and physiological damage. Second, international legal standards and the laws of other countries prohibit the imposition of solitary confinement under the circumstances of the Detainees' case.

\section{The Psychological and Physiological Effects of Solitary Confinement}

Psychological Harms of Solitary Confinement: A critical observation of the Brief was that extensive research conducted in prison systems throughout the United States and in many other countries is "remarkably consistent" in finding that prolonged solitary confinement inflicts "deleterious psychological effects.” (Brief, pp. 8-9 citing Bennion, 2015). In fact, “[n] early every scientific inquiry into the effects of solitary confinement over the past 150 years has concluded that subjecting an individual to more than 10 days of involuntary segregation results in a distinct set of emotional, cognitive, social, and physical pathologies." (Brief, p. 9 citing Appelbaum, 2015).

Decades of case studies, articles, and personal accounts from the United States and around the world show that solitary confinement produces a "strikingly consistent" set of "psychiatric symptoms" in prisoners (Brief, p. 12 citing Appelbaum, 2015). These harms include anxiety, panic, withdrawal, hypersensitivity, ruminations, cognitive dysfunction, hallucinations, loss of control, irritability, aggression, rage, paranoia, depression, a sense of impending emotional breakdown, self-mutilation, and suicidal ideation and behavior (Brief, p. 12 citing Haney, 2003).“'Even those without a prior history of mental illness' are at serious risk of developing these precise symptoms." (Brief, p. 12 citing Appelbaum, 2015).

Medical studies have documented the troublingly high rate of psychological disturbances among isolated inmates. For example, “Dr. Grassian's 1983 study of isolated inmates at Walpole, Massachusetts, provides one striking record of the prevalence of psychopathology in solitary confinement" (Brief, p. 14 citing Grassian, 1983). In the study, "[h] alf of the interviewed inmates suffered from 'difficulties with thinking, concentration, and memory' - with a quarter reporting 'acute confusional states;'” “" $[\mathrm{t}]$ wo-thirds exhibited "hyperresponsivity to external stimuli;"” and "[h] alf had experienced 'hallucinations,' such as 'hearing voices,' and 'perceptual distortions,' like seeing ' $[\mathrm{t}]$ he cell walls start wavering.'” (Brief, p. 14 citing Grassian, 1983). In addition, “ $[\mathrm{t}]$ wo-thirds suffered from 'massive free-floating anxiety,' while nearly half experienced obsessive thoughts like 'primitive aggressive fantasies' and 'persecutory fears.'” (Brief, p. 14 citing Grassian, 1983).

Other studies concluded that " $[\mathrm{t}] \mathrm{he}$ psychological trauma inflicted by solitary confinement results in extraordinarily high rates of self-harm" in prisoners - a rate much higher than that of inmates held in the general population (Brief, p. 16 citing CANY, 2004). For example, a 2014 study of New York City jails reported that while "only $7.3 \%$ of admissions included any solitary confinement, $53.3 \%$ of acts of self-harm and $45.0 \%$ of acts of potentially fatal self-harm occurred within this group."(Brief, p. 16 
citing Kaba, 2014). The analysis in this study "of 244,699 incarcerations revealed that exposure to solitary confinement increased the odds of experiencing self-harm by 6.89 times and potentially fatal self-harm by 6.27 times."(Ibid).

Even after release from prolonged solitary confinement, studies indicate that inmates "may continue to suffer psychological damage 'severe enough to cause near permanent mental and emotional damage."” (Brief, p. 17 citing Vasiliades, 2005). The lasting mental health implications of "prolonged isolation include the inability to initiate or control behavior or interact with other people, loss of one's sense of self and control over emotions, and withdrawal into a fantasy world." (Brief, p. 18 citing Haney). Because prolonged solitary confinement transforms inmates' personalities, they subsequently grapple with an altered self-image, as well as overwhelming feelings of inadequacy, "invalidating stigmas, relived abuse, uncontrollable paranoia or anxiety, self-imposed seclusion, [and] difficulties with sexual intimacy.” (Brief p. 18 citing Martel, 1999).

The Amici concluded that the Detainees claim to have experienced many of the same psychological disturbances as those recorded in the medical and scientific research and that the medical and scientific research supports the claim that the Detainees' post-incarceration suffering resulted from their prolonged solitary confinement.

Physiological Harms of Solitary Confinement: The Brief also demonstrated that the deleterious health effects of solitary confinement are not only psychological but physiological as well. Indeed, experts have found numerous corresponding physiological consequences among inmates subjected to solitary confinement. The litany of negative health effects associated with even a short period of solitary confinement has been noted in health studies from around the world and includes insomnia, headaches, lethargy, dizziness, heart palpitations, appetite loss, weight loss, severe digestive problems, diaphoresis (i.e., profuse sweating), back pain, joint pain, deteriorated vision, shaking, chills, and aggravation of preexisting medical problems (Brief, p. 20 citing Fujio, 2013).

A number of medical studies also have documented the highly prevalent physiological symptoms among inmates held in solitary confinement. For example, “Dr. Haney's 1993 Pelican Bay study revealed that more than $80 \%$ [of prisoners in solitary confinement] suffered from headaches, lethargy, and troubled sleep," and "[o]ver 50\% experienced loss of appetite, dizziness, nightmares, heart palpitations, and perspiring hands." (Brief, pp. 21-22 citing Haney, 2003).

In addition to the immediately apparent effects of solitary confinement on the human body, studies strongly suggest that solitary confinement can fundamentally alter the structure of the human brain in profound and permanent ways (Brief, p. 26). For example, "Dr. Huda Akil, a neuroscientist and specialist in the effects of emotions and stress on brain structure and function, reports that each key characteristic of solitary confinement-lack of physical activity, meaningful interaction with others and the natural world, and visual stimulation - 'is by itself sufficient to change the brain ... dramatically, depending on whether it lasts briefly or is extended,' even just for days." (Brief, p. 25 citing Allen, 2014). As is the case with psychological harms, " $[t]$ his neurological damage, and other physiological harms inflicted by solitary confinement can be long-lasting, even permanent. Several studies conclude that the decline in brain activity that occurs in solitary confinement, 
as confirmed by EEGs, can be irreversible if isolation is prolonged," as it was in this case (Brief, p. 26 citing Shalev, 2008).

Based on these studies, the Amici thus concluded that in addition to the immediately apparent physiological harms that the Detainees suffered during solitary confinement, the Detainees endured physiological effects that may be long-lasting or even permanent (Ibid).

Solitary confinement under international law: Finally, the Amici argued that under international standards, the use of solitary confinement on the Detainees was impermissible because it was (i) based on religion or race; (ii) based on the pretext of immigration violations; and (iii) used as a measure of first, not last, resort. The Amici further argued that, even if the use of solitary confinement had been justified in this case, the indefinite, prolonged duration and extreme conditions imposed violated international laws.

International legal standards recognize that solitary confinement qualifies as torture, as well as cruel and inhuman treatment of prisoners. Under international laws, "torture" and "cruel and inhuman treatment" both refer to "the infliction of 'severe physical or mental pain or suffering." (Brief, p. 28 citing ICRC, n.d.). Torture, additionally, is inflicted for "a specific purpose," like "obtaining . . . information or a confession" or "any reason based on discrimination of any kind." (Ibid). Based on these standards, the Amici concluded that both of these purposes motivated the imposition of solitary confinement in this case and, therefore, amounted to torture and cruel and inhuman treatment.

\section{Conclusion}

The Detainees in this case alleged that, after the September 11 th attacks, they were held for months as "terrorism suspects" in solitary confinement in federal prison solely on the basis of their religion or race. After they were cleared and deported from the United States, the Detainees brought several claims against various high-ranking Government Officials for damages as a result of the harms they suffered. In 2016, after the Court of Appeals for the Second Circuit ruled that the Government Officials could be sued for damages, the Government Officials appealed to the Supreme Court of the United States. The Supreme Court reversed the decision of the Court of Appeals, ruling that the Detainees' claims were insufficient as a matter of law and that the Detainees were prohibited from seeking damages for the harms they suffered.

While this landmark case ultimately denied the Detainees' claims, it exposed widespread use of solitary confinement in the United States, as well as the punishment that many illegal aliens and others suffered in the immediate aftermath of the September 11 th terrorist attacks. The case also provided an opportunity to the Detainees and others to challenge the regular use of solitary confinement and other conduct in United States prisons that amounts to torture under international standards. Given this opportunity, the Amici, a group of prominent professionals from around the globe, submitted the Brief in order to detail the established, well-documented, and exhaustive medical and other scientific and health-related research that virtually unanimously concludes that prolonged solitary confinement inflicts profound psychological and physiological on inmates. The Brief demonstrated to the Supreme Court Justices and others that the Detainees in this case were subjected to treatment that experts condemn as tantamount to torture. The Brief further demonstrated that the imposition of solitary confinement on the 
Detainees violated international legal standards and norms. And, until the practice of solitary confinement is outlawed, the Brief serves as a model for others who, in the future, again seek to challenge the use of solitary confinement in the courts.

\section{References}

Allen, K. (2014). Researchers Study Effects of Prolonged Isolation Among Prisoners, The Toronto Star (Feb. 14, 2014). Retrieved from https:// www.thestar.com/news/world/2014/02/14/ researchers_study_effects_of_prolonged_isolation_among_prisoners.html

Appelbaum, K. (2015). Am. Psychiatry Should Join the Call to Abolish Solitary Confinement, $43 \mathrm{~J}$. Am. Acad. Psychiatry \& L. 406, 410.

Bennion, E. (2015). Banning the Bing: Why Extreme Solitary Confinement is Cruel \& Far Too Usual Punishment, 90 Ind. L. J. 741, 756.

Bivens v. Six Unknown Named Agents of Federal Bureau of Narcotics, 403 U.S. 388 (1971).

Brief Of Medical And Other Scientific And HealthRelated Professionals As Amici Curiae In Support Of Respondents And Affirmance, Ziglar v. Abbasi, No. 15-1358 (Dec. 22, 2016). Retrieved from https://ccrjustice.org/sites/default/ files/attach/2016/12/Medical and Other_Scientific_and_Health-Related_Professionals_Amicus.pdf ("the Brief" or "the Solitary Confinement Brief").

CANY (2004). Mental Health in the House of Corrections: A Study of Mental Health Care in New York State Prisons, pp. 58-59.

Center for Constitutional Rights (2017). Ziglar v. Abbasi (formerly Turkmen v. Ashcroft). Retrieved from https://ccriustice.org/ziglar-v-abbasi.

Fujio, C. et al., (2013). Physicians for Human Rights, Buried Alive: Solitary Confinement in the U.S. Detention System, pp. 1-2.

Grassian, S. (1983). Psychopathological Effects of Solitary Confinement, 140 Am. J. Psychiatry $1450,1453$.

Haney, C. (2003). Mental Health Issues in Long Term Solitary and "Supermax" Confinement, 49 Crime \& Delinq. 124, 130-31.

International Committee of the Red Cross (ICRC) (n.d.). Customary IHL - Rule 90, Torture \& Cruel, Inhuman or Degrading Treatment. Retrieved from https://ihldatabases.icrc.org/ customary-ihl/eng/docs/v1_rul_rule90.

Kaba F. et al. (2014). Solitary Confinement \& Risk of Self-Harm Among Jail Inmates, 104 Am. J. of Pub. Health 442, 442.

Martel, J. (1999). Solitude \& Cold Storage: Women's Journeys of Endurance in Segregation, Elizabeth Fry Soc'y of Edmonton, 87.

Shalev, S. (2008). A Sourcebook on Solitary Confinement, Mannheim Centre for Criminology, London School of Economics and Political Science, 20.

Memorandum Opinion, Turkmen v. Hasty, No. 13-981 (2d Cir. June 17, 2015). Retrieved from https:// ccrjustice.org/sites/default/files/attach/2015/06/ Turkmen $\% 20 \mathrm{v}$. $\% 20$ Ashcroft $\% 20$ Second $\% 20$ Circuit\%20Ruling\%206-17-15.pdf

Fourth Amended Complaint, Turkmen v. Ashcroft, No. 02 CV 2307 (SMG) (E.D.N.Y. Sept. 13, 2010) (the "Complaint").

United Nations General Assembly (2015) Res. 70/175, Rule 44. Retrieved from http://www. un.org/en/ga/search/view_doc.asp?symbol=A/ RES/70/175 ("the Nelson Mandela Rules")

Vasiliades, E. (2005). Solitary Confinement \& Int'l Human Rights; Why the U.S. Prison System Fails Global Standards, $21 \mathrm{Am}$. U. Int'l L Rev. 71, 76-77.

Ziglar v. Abbasi, No. 15-1358, 137 S. Ct. 1843 (2017). 